EESTI NSV TEADUSTE AKADEEMIA TOIMETISED 1954. III kd., nr. 4 ИЗВЕСТИЯ АКАДЕМИИ НАУК ЭСТОНСКОИ ССР 1954. ТОМ III, № 4

\title{
ОТРАЖЕНИЕ БОРЬБЫ ЭСТОНСКОГО КРЕСТЬЯНСТВА В ГОДЫ ПЕРВОЙ РУССКОЙ РЕВОЛЮЦИИ В ТВОРЧЕСТВЕ \\ Х. МЕЛЬДЕРМАНА
}

\author{
и. п. СОЛОМЫКОВА, \\ кандидат искусствоведческих наук
}

Деятельность представителей эстонской демократической культуры полностью замалчивалась буржуазными искусствоведами, а история эстонского искусства революционного времени, больше чем какого-либо другого периода, подвергалась буржуазно-националистическим извращениям.

Эстонские советские искусствоведы до сих пор мало уделяли внимания изучению искусства периода революции 1905-1907 годов. Сделана только одна попытка в этой области - В. Тийк показала связь творчества художника А. Лайкмаа с событиями революции '.

Исследование этого периода в эстонском изобразительном искусстве имеет тем большее значение, что именно в 1905-1907 годах эстонское искусство впервые поднялось до социально-критического реализма, до прямого обличения самодержавия, и в нем также возникли новые, революционные элементы.

Развитие эстонского изобразительного искусства, как и всей эстонской национальной культуры, тормозилось тяжелым экономическим и национальным гнетом прибалтийских баронов и самодержавия. Эстонское национальное искусство начало развиваться несколько быстрее в обстановке развернувшегося в 50-60-х годах прошлого века национального движения. Оно развивалось в упорной борьбе с господствующей реакционной клерикальной культурой, выражавшей интересы прибалтийского дворянства и немецкой буржуазии.

Русское реалистическое искусство оказало на развитие эстонского искусства значительное воздействие. Под его влиянием эстонское искусство во второй половине XIX века становилось на путь овладения реализмом. Но эстонское искусство еще не отражало глубоко жизнь народа и не дошло до открытого протеста и обличения господствующего порядка. В творчестве наиболее выдающегося эстонского художника и передового общественного деятеля второй половины XIX века - И. Кёлера (1826-1899) уже звучит, правда еще в аллегорической форме, критика прибалтийского дворянства и пасторов («Пробуждение от волшебного сна», 1865 и «Проклятие Лорелей монахами», 1887).

1 V. Tiik, A. Laikmaa esimese vene revolutsiooni ajajärgul. „Sirp ja Vasar”, 21. XI 1952. 
В связи с дальнейшим обострением социальных противоречий и вступлением на историческую арену пролетариата в эстонском искусстве происходят значительные сдвиги, развиваются новые идейно-художественные тенденции. Эти новые явления связаны с творческой деятельностью Кристьяна Рауда (1865-1943) и Пауля Рауда $(1865-1930)$ и особенно с деятельностью Антса Лайкмаа (1866-1942).

Раннее творчество крупного эстонского графика К. Рауда характеризуется стремлением художника глубже изучить и отразить жизнь народа, причем особенное внимание он уделяет изображению жизни бедных слоев населения, жизни, полной лишений, тяжкого труда и горя. Об этом свидетельствуют рисунки «Жестянщики», «Уборка картофеля», «При свете свечи», «Пряха» и некоторые другие. Несмотря на то, что сам художник был довольно далек от активной общественно-политической жизни, большая социальная правда, выраженная в его произведениях, заставляет зрителей проникаться глубоким сочувствием к труженикам и чувством протеста против социальной несправедливости., В творчестве К. Рауда 80 - 90 -х годов зарождаются начала критического реализма в эстонском изобразительном искусстве, в частности в графике.

Творчество выдающегося эстонского художника А. Лайкмаа периода его расцвета (1900-1907 гг.) явилось связующим звеном между эстонским искусством XIX века и эстонским искусством периода револющии 1905 года. Глубоко восприняв лучшие традиции русского искусства, будучи тесно связан с общественной жизнью, Лайкмаа под воздействием роста революционного движения становится активным борцом за глубоко идейное, реалистическое искусство, служащее народу. А. Лайкмаа - выдающийся мастер социально-психологического портрета. Создавая портреты Л. Н. Толстого (1904), А. М. Горького (1905), портрет революционно настроенного крестьянина («Старый Айтсам», 1904), художник утверждал идеалы борьбы со старым миром за революционное переустройство общества. Откликаясь на выступления пролетариата России летом и осенью 1905 года, которые потрясли до основания самодержавнопомещичью и капиталистическую Россию, Лайкмаа с энтузиазмом создает символический образ революционного рабочего, разорвавшего вековые оковы рабства и высоко поднявшего красное знамя восстания. Рисунок был сделан для обложки первого эстонского пролетарского литературнохудожественного альбома «Эдази» («Вперед»). В эти годы Лайкмаа стал крупнейшим эстонским художником-реалистом, служившим примером молодым демократическим художникам.

Развитие эстонского искусства во второй половине XIX века и накануне первой русской революции создало некоторые предпосылки для возникновения эстонской демократической графики 1905-1907 годов. Демократическая реалистическая графика периода 1905-1907 годов представляет собой этап в истории как эстонской графики, так и всего эстонского изобразительного искусства. В этот период эстонское демократическое искусство сделало большой шаг вперед в своем развитии по пути критического реализма, а в творчестве А. Лайкмаа и Х. Мельдермана приблизилось к революционному искусству.

Подлинно передовым, новаторским, революционным по своей идейной направленности и реалистическим по методу художественного воплощения, несмотря на недостатки в мастерстве, было творчество замечательного художника-самоучки, выходца из народных масс - Ханса Мельдермана $(1876-1914)^{2}$.

2 Реакционные буржуазные искусствоведы, в угоду господствующему классу фальсифицировавшие историю эстонского искусства, полностью замалчивали факт существования художника Мельдермана и его творчества. Впервые о нем сообщалось автором настоящей статьи в газете «Сирп я Вазар» от 4 II 1954 r. 
В эти годы, в обстановке революции, графика, особенно специфическижурнальная графика, стала наиболее распространенным видом эстонского изобразительного искусства. В Эстонии, как и во многих других местах России, возникли передовые сатирические журналы, широко использовавшие как публицистику и сатирическую литературу, так и реалистический рисунок, особенно сатирическую графику и карикатуру. Становление и быстрое развитие политического рисунка, сатиры и карикатуры характернейшая черта изучаемого периода.

Большую роль в развитии передовой журнальной графики этого периода сыграли сатирические журналы пролетарского писателя-публициста Юхана Лилиенбаха, широко иснользовавшего сатирическую графику и сатирический рисунок как оружие в борьбе против баронов, пасторов и самодержавия. В журналах Ю. Лилиенбаха Мельдерманом была опубликована серия рисунков - художественно-документальная хроника «Военное положение в Эстляндии». В этих рисунках, связанных единой темой, показаны наиболее важные моменты вооруженной борьбы эстонских рабочих и крестьян против помещиков, а также разоблачены зверства карательных отрядов.

Х. Мельдерман родился в уезде Ляэнема, волости Мярьяма, в деревне Толли, где его отец был школьным учителем ${ }^{3}$. Купив впоследствии небольшой участок земли, отец его занялся сельским хозяйством. Было не легко дать образование четырем детям, из которых двое - Ханс и его сестра Мари - интересовались рисованием. Ханс Мельдерман самостоятельно занимался рисованием. Об его упорной работе над рисунком свидетельствуют многочисленные сохранившиеся альбомы с зарисовками, главным образом портретами, срисованными, очевидно, из журналов.

Из-за тяжелого материального положения X. Мельдерману не удалось получить никакого художественного образования. В Таллине в конце XIX и в первых годах XX века не было ни художественной школы, ни частных художественных курсов. Желающие изучать искусство устремлялись в Петербург, где в Художественно-промышленном училище барона Штиглица училось много эстонцев. Только лишь в 1903 году художник А. Лайкмаа открыл в Таллине, в своей мастерской курсы рисования и живописи. На этих курсах в 1904-1905 годах в течении нескольких месяцев училась и Мари Мельдерман.

Х. Мельдерман, находясь в стесненных материальных условиях, работал с 1897 по 1898 год в г. Валга в качестве помощника школьного учителя, позднее учителем в Ридала, в волости Мяэвальд (Ляэнема). В 1903 году он поступил на работу в фотоцинкографическую мастерскую Томсона в Таллине, где изготавливались клише. Это событие имело большое значение в жизни Мельдермана. В Таллине - одном из важнейших промышленных и культурных центров Эстонии - он постепенно стал выполнять все больше заказов на иллюстрации, а также публиковать свои карикатуры в юмористических изданиях.

Первый период творчества Мельдермана охватывает 1903-1904 годы. В это время Мельдерман сделал много для развития эстонской демократической журнальной графики, иллюстрируя доступные народу многотиражные юмористические издания, журналы и т. д. Так как в области эстонской карикатуры отсутствовали сложившиеся традиции, на которые мог бы опереться художник, то для Мельдермана особое значение приобретает обращение к народному творчеству, к народной сатире и народному юмору. Используя народную традицию, Мельдерман в то время

3 Республиканский архив актов гражданского состояния Эстонской ССР, архив 1788, № 158 , архив 1802, № 26. 
проявляет большую творческую инициативу и находчивость. Его карикатуры всегда самобытны, и их сочный, народный юмор резко отличает их от пошлых карикатур, скопированных зачастую из немецких юмористических журналов.

Карикатуры Мельдермана теснее чем рисунки других художников связаны с народной жизнью. Хорошо зная быт простого народа в городе и деревне, Мельдерман черпает тематику своих карикатур из окружающей жизни. Почти всегда он изображает конкретных людей и события, имевшие место в действительности. Острие его карикатур зачастую направлено против богатого хуторянина. Он высмеивает его жадность, алчность, его неопрятный образ жизни. Мельдерман высмеивает баптистов, а также тех, кто их слушает и верит им, и т. д.

Почти все карикатуры Мельдермана периода 1903-1904 годов опубликованы анонимно. Изучение эпистолярного наследия и архива X. Мельдермана дало возможность точно установить его авторство в отношении многих карикатур. Так, например, удалось установить, что он является автором серии карикатур «Примерный хозяин». Эти карикатуры опубликованы в юмористическом издании «Налья-Вана» (Таллин, 1903 г.). Это первые характерные примеры эстонской народной по духу, реалистической карикатуры начала XX века.

В 1905 году вышла в Таллине книга «Kavala Hansu ja vanapagana lugu» («История о хитром Хансе и старом чёрте») с 50 иллюстрациями. В книге не указана фамилия иллюстратора, но на основании сравнения черновых рисунков Мельдермана с иллюстрациями можно утверждать, что автором этих иллюстраций является Ханс Мельдерман. Книга была выпущена массовым тиражом и благодаря доходчивым юмористическим рисункам завоевала признание самого широкого круга читателей.

По своей основной направленности карикатуры Мельдермана ограничивались высмеиванием и осуждением уродливых явлений быта города и деревни, не доходя еще до социального обличения. Но в них уже были заключены элементы критического отношения к социальной действительности. В годы революции эти элементы развились до уровня революционно-политической сатиры. Карикатуры Мельдермана были широко известны в народе и пользовались большой популярностью.

Большое принципиальное значение для творчества Мельдермана и определения его места в истории эстонского искусства имеют те произведения, которые были созданы им во второй период его творчества - во время революции 1905-1907 годов. Под воздействием революционной действительности и борьбы народа против баронов и самодержавия в творчестве Мельдермана происходит решительный перелом. Содержанием его творчества становится революционная борьба эстонского народа. В эти годы он вырастает в выдающегося мастера реалистической обличительной графики.

В это время Мельдерман познакомился с пролетарским писателем Ю. Лилиенбахом. Знакомство их состоялось, очевидно, в мастерской Томсона, где Ю. Лилиенбах заказывал клише для илдюстрирования своих изданий. Там же Мельдерман познакомился с Лайкмаа.

Мельдерман был в это время уже сложившимся, образованным человеком с широким кругозором. На формирование его демократического мировоззрения в юности оказала сильное влияние демократическая газета «Сакала», которую его отец, школьный учитель, выписывал, несмотря на угрозы помещика. Свободно владея русским языком, Мельдерман. читал в подлинниках произведения русских писателей и особенно Льва Толстого. Интересы Мельдермана отличались разносторонностью - он рисовал карикатуры, портреты, пейзажи, делал иллюстрации, сочинял ша- 
рады, ребусы, писал стихи, а также играл на рояле, на скрипке. Қак художник-карикатурист он пользовался большим успехом. Народ уважал его за честность, смелость, прямоту характера ${ }^{4}$.

Знакомство с Ю. Лилиенбахом оказало на Мельдермана очень большое влияние. Несмотря на то, что в карикатурах Мельдермана уже и в 1903-1905 годах звучали нотки критического отношения к социальной действительности, он еще не понимал, что сатирическое, целенаправленное искусство может быть острым оружием разоблачения и осмеяния о с но в но го з л а царской России - существовавшего самодержавного, полукрепостнического режима, - частью освободительной борьбы народа. Именно Ю. Лилиенбах помог Мельдерману осознать его место и задачи в освободительной борьбе эстонского народа против самодержавия и помещиков, помог Мельдерману вступить на путь бесстрашного разоблачения оружием искусства преступлений, совершаемых царизмом против народа.

О тесных связях Мельдермана и Лилиенбаха свидетельствуют некоторые сохранившиеся письма. Большой интерес представляет письмо Х. Мельдермана сестре от 29 апреля 1906 года. Из письма явствует, что Мельдерману было дано задание сделать рисунки для выходящих на русском и эстонском языке в Петербурге «листков».

Там же отмечается, что долгожданное разрешение для издания «листка» теперь получено, оба «листка» будут выходить в Петербурге. Мельдерман пишет, что должен собрать все сведения о недавних «горячих событиях» в деревне и дать к ним рисунки. Для этого он срочно выезжает в деревню. Здесь речь идет об издании в Петербурге братьями Петером и Юханом Лилиенбахами эстонского сатирического журнала «Тию Тазане», первый номер которого вышел в мае 1906 года. Возможно, что зная болышие способности Мельдермана, его склонность к сатире, его демократическое мировоззрение, именно Ю. Лилиенбах подсказал ему мысль о создании художественно-документальной хроники революционных событий в эстонской деревне. Это предположение подтверждается письмом Ю. Лилиенбаха к Мельдерману из Таллина. Приводим его полностью.

«Милый Мельдерман!

Очевидно, я не ответил на Ваше письмо - не хватает времени - а также не выслал листок. Теперь посылаю № 2 и 3. № 4 - выходит. Ваши рисунки получил, но они еще не использованы. Надо иногда печатать и другие. Нельзя становиться односторонним. - Вы говорите, что у Вас есть несколько заказов и ждете больше. Зачем же ждать? Желательно было бы, чтобы Вы каждый отдельный заказ послали бы в Петербург на почтовой открытке. Открытка стонт всего 3 коп. Деньги кассируйте, когда сами захотите. Их получите, конечно, себе за работу. Для более длинного письма нет времени.

Таллин, 23/7.06*5.

С приветом Ю. Лилиенбах.

В письме речь идет о втором и третьем номерах журнала «Тию Тазане», которые к этому времени уже вышли. Ожидалось издание и четвертого номера - уже под названием «Таппер» ${ }^{6}$. Как известно, на третий номер «Тию Тазане» из-за его революционного содержания царской цензурой был наложен арест. В результате следствия, которое дли-

4 Биографические сведения о Х. Мельдермане установлены на основании его архива, переданного в наше распоряжение его сестрой М. Мельдре (быв. Мельдерман, проживает в колхозе «Пунане Тяхт», Мярьямаского района), а также на основании ее устных рассказов.

5 Перевод с эстонского.

6 Официальным редактором-издателем журнала жТию Тазане» был брат Юхана Лилиенбаха - Петер Лилиенбах. Фактически почти вся работа выполнялась Юханом Лилиенбахом. 
лось несколько лет, редактор-издатель «Тию Тазане» П. Лилиенбах был подвергнут, на основании приговора Петербургской судебной палаты, аресту при полиции на десять дней; этим же приговором издание «Тию Тазане» было запрещено навсегда. Из материалов следствия известно, что одной из причин запрещения журнала были рисунки революционного содержания. В материалах следствия указывается, что в этих рисунках проводится мысль, что правительство вместо реформ дает народу только виселицы и вводит военное положение ${ }^{7}$. Одним из авторов этих рисунков и был Х. Мельдерман.

Из приведенного письма видно, что Ю. Лилиенбах, в целях сохранения журнала, был вынужден временно подождать с печатанием рисунков Мельдермана, ибо их опубликование могло стать роковым для судьбы журнала.

В первом номере «Тию Тазане» опубликована заметка, озаглавленная «Военное положение в Әстляндии». Редакция сообщает читателям, что в следующих номерах под заголовком «Военное положение в Эстляндии» будет напечатан ряд рисунков об ужасах прошлой зимы в России. В первом номере «Тию Тазане» были напечатаны два рисунка Х. Мельдермана. Ю. Лилиенбах охарактеризовал художника следующими словами: «Г-н X. M. научился рисовать сам, благодаря упражнению и своим способностям. В своих рисунках он оставляет без внимания новейшие течения и требования модного искусства, но у него хорошая память и большие способности. Он также хорошо знает жизнь нашего крестьянства, в большей части он своими глазами видел те события, которые изображает. Он выписывает свои композиции с фотографической тщательностью, так что они приобретают историческое значение. Из последующих рисунков назовем: Сожжение помещичьего имения. В тюрьме. Военно-полевой суд. Исполнение судебного приговора. Могила революционера. Сожжение крестьянского дома. В суровый край и др. ${ }^{8}$.

Как видим, рисунки Мельдермана были задуманы как историко-художественная документальная хроника революционных событий в Ляэнема. Художник выбрал наиболее важные, узловые моменты борьбы и рассказал о них средствами искусства. Задачи, которые поставил себе Мельдерман, были большие и ответственные, и он смело взялся за их разрешение. Очень важно замечание Ю. Лилиенбаха, сделанное как-будто вскользь, но имеющее большое принципиальное значение - Х. Мельдерман является реалистическим художником, он оставляет без внимания так называемые «модные» течения, т. е. формализм в искусстве. В своих произведениях он руководствуется только лишь действительностью, причем делает отбор фактов и обобщает их. Целью художника является показ жизненной правды во всей ее суровости.

Очень ценным является стремление Мельдермана к типичности, к большим обобщениям. Искусство только тогда является настоящим искусством, когда оно - не только отклик на события, но и результат глубокого и тщательного изучения изображаемого события или явления. Для Мельдермана характерна именно эта черта, а также настойчивое стремление найти наилучшее художественное воплощение своих замыслов.

Приступая, очевидно, в апреле 1906 года (возможно и вполне вероятно, что отдельные наброски, эскизы, были сделаны раньше) к созданию своей художественно-документальной хроники, он не ограничивается своими воспоминаниями (хотя именно непосредственные впечатления имели для него огромное значение - они воспитали в нем неугасимую

7 ЦГИАЛ, фонд 776, ед. хр. 177. стр. 14 оборотная.

8 ,Tiiu Tasane", Politikaline ilukirjanduse, pilkenalja ja pildiajakiri, nr. 1, Peterburi, 1906, lk. 6 . 
ненависть к душителям народной свободы) и едет в деревню, чтобы на месте собрать все сведения, еще раз проверить свои впечатления, тщательно изучить события, собрать дополнителыный материал.

Основной темой рисунков Мельдермана является вооруженное восстание рабочих и крестьян в декабре 1905 года в Ляэнема и последовавшие в начале 1906 года жестокие репрессии со стороны карательных отрядов.

Художник тщательно обдумывает каждый рисунок, выбирая самое существенное, самые характерные детали. Первый рисунок из серии, өчевидно, не смог быть напечатан из цензурных соображений. В «Тию Тазане» № 1 был опубликован рисунок «Военное положение в Эстляндии II. Идемте с нами!» ${ }^{9}$. Здесь изображено типичное для декабря 1905 года

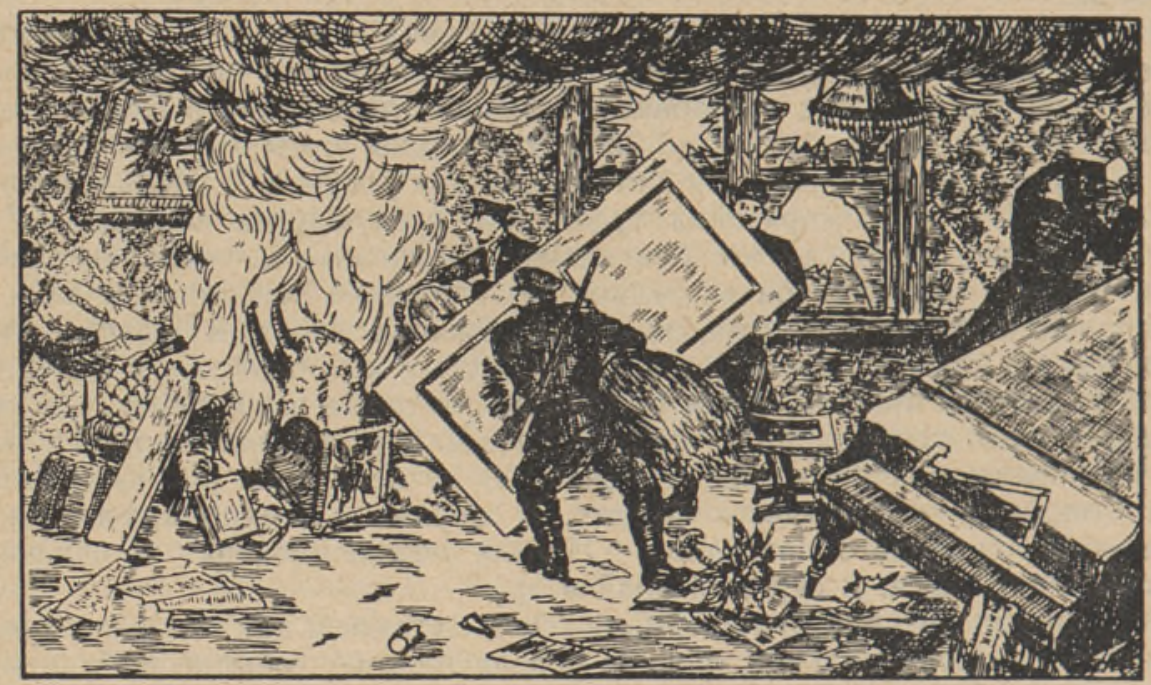

1. Военное положение в Эстляндии III. Разгром помещичьего имения. «Тию Тазане», № 3,1906 , стр. 8 .

в Әстонии явление: рабочие, вооруженные ружьями и револьверами, входят в деревенскую избу и зовут крестьян с собой на борьбу с помещиками, громить помещичьи имения. Художник сумел убедительно показать. ведущую роль эстонских рабочих во время вооруженного выступления в декабре 1905 года. В рисунке Мельдерман хорошо передал революционное настроение, охватившее трудящиеся массы Әстонии в момент кульминации революции.

Последовавшие события, особенно бурно развивавшиеся там, куда прибыли отряды рабочих, мы видим на рисунке «Военное положение в Эстляндии III. Разгром помещичьего имения». Гнев крестьян, боров-

9 Римская цифра II указывает на то, что существовал рисунок «Военное положение в Эстляндии І», который не был, очевидно, напечатан из цензурных соображений. Сам Юхан Лилиенбах писал в 1917 г. об этом следующее: «... Первый номер нам удалось спасти от конфискации и суда таким образом, что прежде чем формально получили бумагу о наложении ареста, сообщили в цензурный комитет о находившихся под. обвинением рисунках, что решили их не печатать». (См. «Таппер», 1917, № 10, Таллин, полоса 323). Это подтверждается также письмом редактора и издателя журнала «Тию Тазане» Петера Лилиенбаха председателю С.-Петербургского Комитета по делам печати от 13 мая 1906 г. с просьбой вернуть рисунки, представленные в двух оттисках и предназначенные для первого номера журнала. Петер Лилиенбах расписался в получении их и обязался их не печатать, а заменить новыми (ЦГИАЛ, фонд 777 , опись 7. ед. хр. 954, стр. 2 ). 
шихся за землю и свободу, против гнета царского самодержавия и произвола помещиков, обрушился прежде всего на помещичьи имения.

На рисунке Мельдермана изображен момент разгрома и поджога имения восставшими крестьянами и рабочимиุ. Они уничтожают имущество, накопленное поколениями помещиков за счет бесчеловечной эксплуатации крестьян. С особенной яростью уничтожают крестьяне и рабочие портреты ненавистных эксплуататоров. Весь этот хлам сваливают в кучу, подбрасывают соломы - и к потолку поднимаются черные клубы дыма.

Несмотря на некоторые погрешности в рисунке и перспективе, оба произведения Мельдермана хорошо продуманы как в композиции, так и в деталях, люди показаны в действии. Рисунки производят сильное впечатление как свидетельство очевидца ${ }^{10}$. В произведениях Мельдермана живет сама действительность, и зритель образно представляет себе событие во всей его конкретности.

Рисунок «Разгром помещичьего имения» был напечатан в «Тию Тазане» № 3 и явился одной из причин, вызвавших запрещение этого журнала ". Реакционеры из царской цензуры хорошо поняли значение и цель рисунков Мельдермана. Рисунки эти обобщали опыт революционной борьбы народа, звали крестьян к продолжению этой борьбы.

Но как во всей России, так и в Эстонии «... крестьяне действовали слишком распыленно, неорганизованно, недостаточно наступательно, и в этом заключается одна из коренных причин поражения революции» 12 . Разбрасывание боевых рабочих отрядов по волостям, уездам, без организации восстания в Таллине, распылило и ослабило силы эстонского рабочего класса.

«Декабрьское восстание 1905 года было высшей точкой революции. В декабре царское самодержавие нанесло восстанию поражение. После поражения декабрьского восстания начался поворот к постепенному отступлению революции. Подъем революции сменился ее постепенной убылью.

Царское правительство спешило воспользоваться этим поражением для того, чтобы добить революцию. Царские палачи и тюремщики развернули свою кровавую работу. Карательные экспедиции в Польше, Латвии, Әстонии, Закавказьи, Сибири свирепствовали во-всю» 13.

Уже в конце декабря в Эстонии стали действовать карательные отряды местных баронов-черносотенцев. В январе в Әстонию прибыли новые карательные отряды, в их числе - отряд генерала Безобразова. С особенной жестокостью свирепствовали они в одном из центров революционного движения - в уезде Ляэнема, как раз в тех местах, где жил и работал художник Мельдерман. Все изображенные им события являются исторически достоверными.

На одном из своих рисунков «В Мярьяма, перед бывшим трактиром «Кукемаа», в январе 1906 г.» художник показал кратковременную остановку карательного отряда Безобразова у старого трактира. Видны беседующие группами солдаты, офицеры, полевая кухня, а в центре рисунка - два орудия на полозьях. Художник отбрасывает все ненужные детали, до предела снижает горизонт - крыша трактира упирается в верхний край рисунка. Этими приемами художник сосредоточивает внимание зрителя на самом карательном отряде, на орудиях. На первый

10 Из рассказов второй сестры художника $M$. Труммаль известно, что в январе 1906 г. Х. Мельдерман был очевидцем всех нзображенных им событий.

11 См. ЦГИАЛ, фонд 776 , ед. хр. 177 , стр. 6-10.

12 В. И. Л ен ин, Соч., т. 23, стр. 241.

13 История Всесоюзной Коммунистической партии (большевиков). Краткий курс, cтp. 80 . 
взгляд нет ничего необычайного в этой сценке из повседневной походной жизни. Однако обличительная сатирическая направленность этого рисунка становится ясной, если сопоставить его с последующими рисунками. Они говорят о том, что царское войско ведет войну против своего народа, против беззащитных женщин, детей и стариков. Подчеркивая именно эту сторону, художник демонстративно помещает на переднем плане орудия. Зловещую атмосферу создает контраст между обыденной деловитостью офицеров и солдат, занятых около орудий и полевой кухни, и знанием зрителя, читателя того, что эти солдаты и офицеры будут совершать затем кровавые преступления против народа (что будет раскрыто в других рисунках Мельдермана).

По следующим рисункам Мельдермана можно проследить дальнейший ход событий в Мярьяма. Карательный отряд Безобразова вместе с

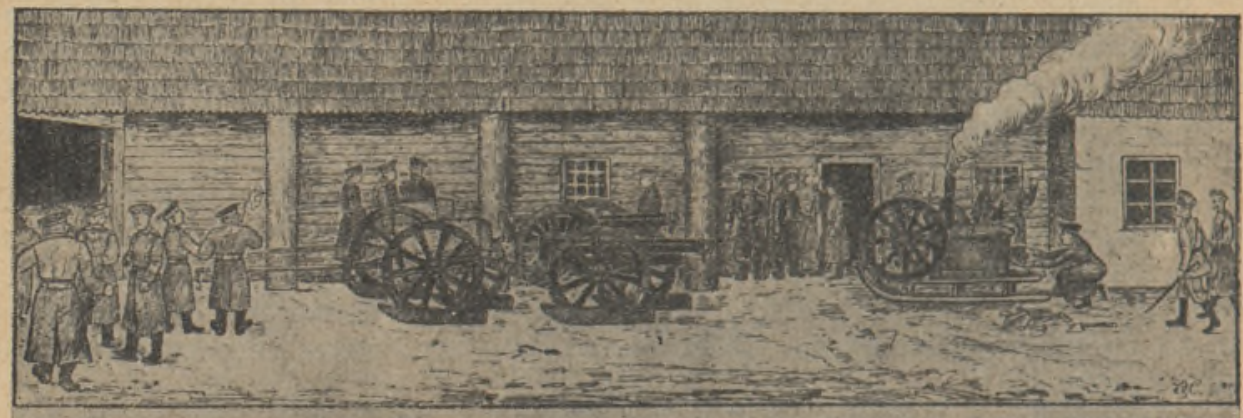

Sôjaseadus Eestimaal. : Märjamaal, endise ‘Kukemaa kortsi ees, jaanuarikuus 1906 â

2. Военное положение в Эстляндии: в Мярьяма, у бывшего трактира «Кукемаа», в январе 1906 г. «Тию Тазане», № 1, 1906, стр. 7.

местными помещиками-баронами организовал массовую кровавую расправу с революционно настроенным крестьянством. Известно, что в Мярьяма было расстреляно три человека и телесному наказанию подвергнуто 79 человек ${ }^{14}$.

Зловещие приготовления к порке видим мы на рисунке, опубликованном в 1906 году в сатирической листовке «Ноолед».

Подчеркнуто гротескными даны фигуры казаков, с большой тщательностью и усердием заготавливающих розги в лесу. С помощью нескольких деталей Мельдерман подчеркивает, что экзекуция подготовляется в массовом масштабе (один из казаков уже удаляется со связкой розог, на переднем плане растет большая куча прутьев). На эскизе к этому рисунку видна лошадь, запряженная в сани, нагруженные розгами. Впоследствии художник убрал эту деталь как ненужную, как перегружающую рисунок - без лошади проще и яснее. На эскизе видим также сатирическую подпись к рисунку, очевидно опущенную Лилиенбахом из цензурных соображений: «Вот свобода!». Мельдерман подчеркивает с острым сарказмом, что это - свобода для царских палачей и баронов, свобода пороть, вешать и расстреливать.

Необходимо остановиться особо на эскизах Мельдермана. Сравнение эскизов с окончательным вариантом рисунка говорит о большой требовательности к себе художника, о тщательном отборе автором художественных средств в поисках наилучшего воплощения замысла. Кроме эскиза

14 Г. И. М о с бе р г, Революция 1905-1907. гг. в Эстонии, Докторская диссертация, 1953 г., Рукопись в Институте истории АН ЭССР в Таллине, стр. $649-652$. 
«Вот свобода!», сохранились еще эскизы к рисункам «Разгром помещичьего имения» и «В суровый край».

Неотъемлемой частью художественно-документальной хроники Мельдермана «Военное положение в Эстляндии» является также рисунокэскиз, переданный нам M. Мельдре, до настоящего времени нигде не опубликованный, являющийся одним из наиболее сильных рисунков ху дожника. С большой силой гнева Мельдерман разоблачает кровавые деяния царизма и баронов.

Мельдерман изображает конкретное, часто имевшее место событие вторжение в крестьянский дом солдат под руководством местного баронапомещика и расправу с революционным крестьянином и его семьей.

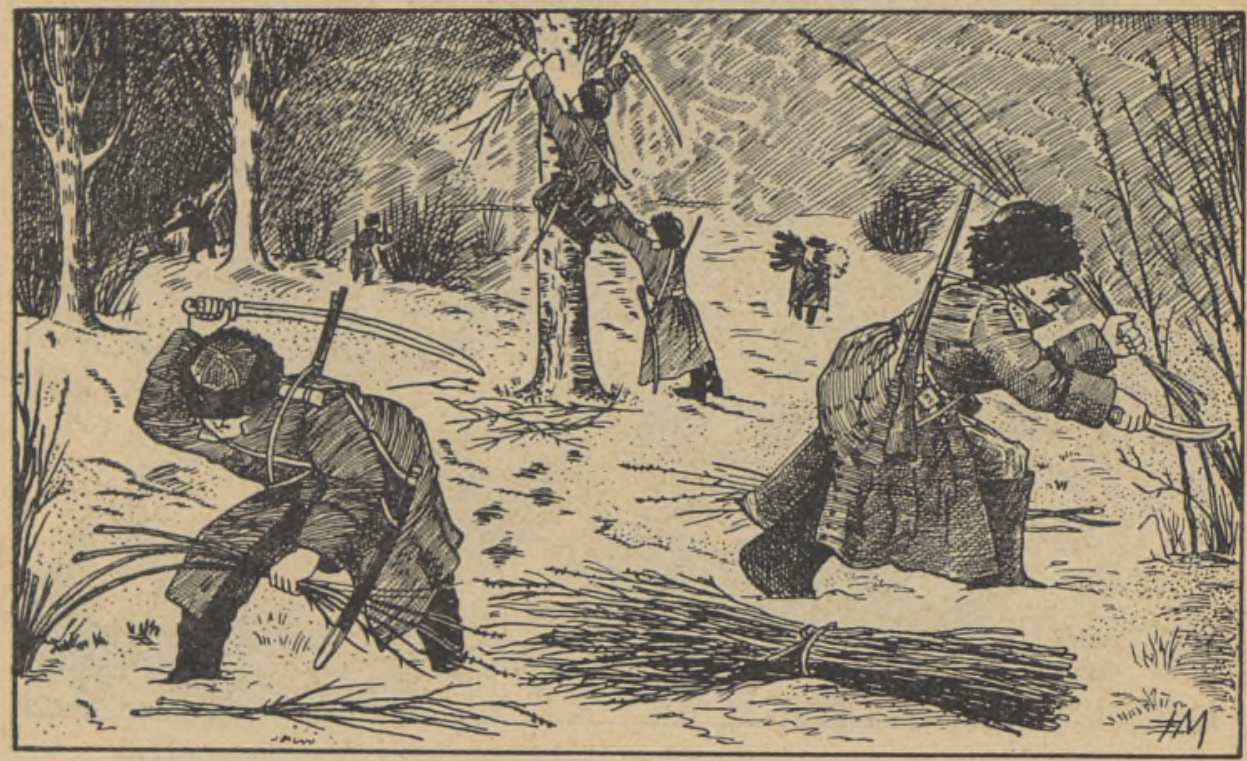

3. Қазаки в лесу. Вот свобода! *Ноолед», 1906, стр. 8.

Художник гневно обличает карателей и баронов, жестоко расправляющихся с мирными жителями. Композиция, построенная на столкновении двух враждебных друг другу социальных сил, полна динамики, захватывает зрителя экспрессивностью и эмоциональностью изображения. Каждая деталь продумана: брошенная на пол швейная машинка, опрокинутый стул, разбитая посуда - все это дополняет картину дикой расправы карателей над крестьянами. Несмотря на то, что фигура барона помещена с краю, в левом углу рисунка, она является по замыслу одной из центральных фигур произведения. Его злобное лицо, повелительно протянутая по направлению к молодому крестьянину рука говорят нам о том, что здесь барон пользуется возможностью свести счеты со своим старым противником. Надо отдать должное Мельдерману - он лучше многих других художников понял и сумел показать, что солдаты являются лишь слепым орудием в руках царского самодержавия и его верных помощников - немецких баронов. Художник сумел показать действительных классовых врагов народа. Эскиз Мельдермана по драматизму действия, огромной эмоциональной выразительности мог быть прекрасным материалом для дальнейшей работы. Однако мы не имеем сведений о том, была ли эта работа завершена. 
К этой же хронике относится переданный нам М. Мельдре эскиз, на котором изображены арестованные крестьяне на полу в комнате под охраной двух солдат. Эскиз незакончен. Тщательно прорисована только печка.

Одним из нанболее выразительных является рисунок Мельдермана «В суровый край», опубликованный в сатирической листовке Лилиенбаха «Ноолед», 1906 г. На рисунке показывается, как после тяжелого телесного наказания крестьян отправляли в суровые края - в Сибирь. Художник хорошо сумел передать типичный ляэнемаский зимний пейзаж, но пейзаж в этом рисунке не существует отдельно, сам по себе, он является неотъемлемой частью содержания и дополняет его. С присущим ему уме-

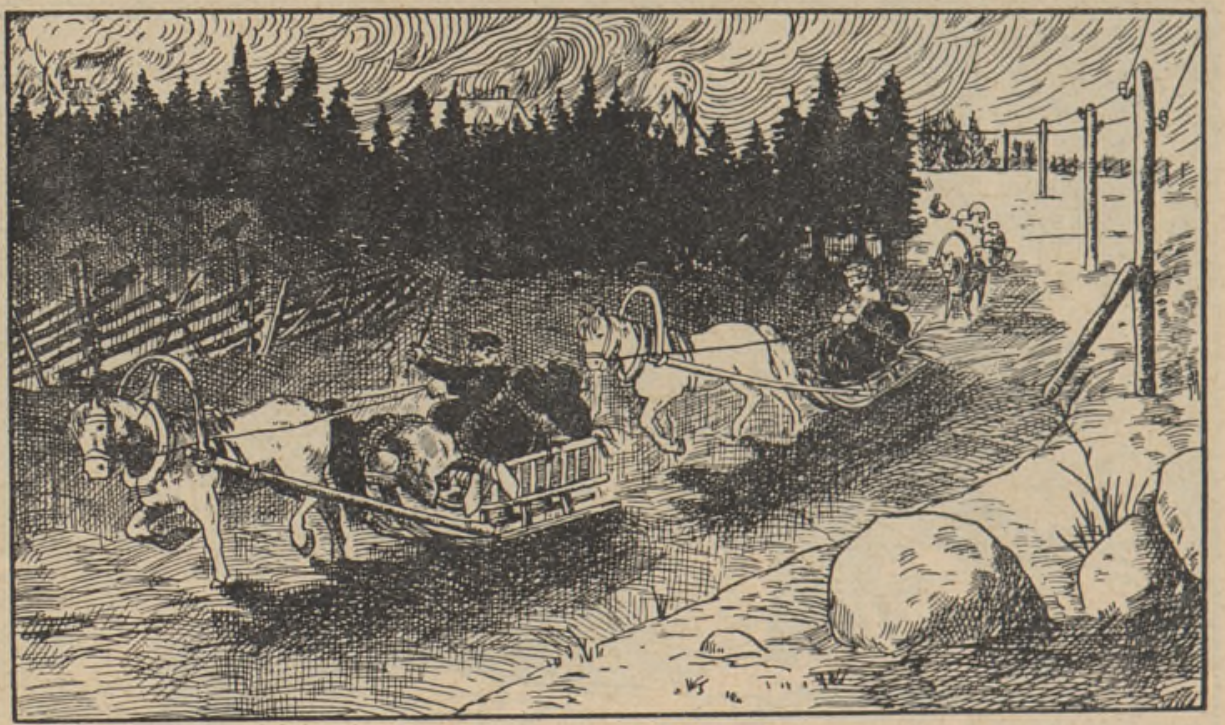

4. В суровый край. «Ноолед», 1906, стр. 9.

нием Мельдерман строит композицию. Из-за мрачного елового леса на шоссе выезжает обоз. Однако стоит пристальнее присмотреться к ездокам на санях, и можно заметить, что на каждых санях, кроме возчика, лежат один или два связанных крестьянина. Мельдерман показывает их лежащими ничком на санях; сидеть в их положении было невозможно. Это характеризует стремление художника к исторически-достоверной художественной детали.

Мрачную атмосферу реакции, жестокие действия карательных отрядов художник умеет передать многими простыми, но многозначительными деталями. Так, например, ничем особенно не выделяется небо, но при внимательном рассмотрении можно заметить, что дым пожарищ застилает его. Это горят подожженные карателями крестьянские усадьбы. Не случайны также вороны на изгороди около дорог - они чуют добычу. Все эти детали, вместе взятые, создают зловещую картину жестоких репрессий - телесных наказаний, убийств, поджогов, высылки и т. д.

Отличительной чертой творчества Мельдермана является умение о м н о го м с к а з а т в во внешне простых рисунках небольшого формата, умение передать сущность явлений.

Рисунки Мельдермана призывали народ к протесту, они вдохновляли на активные революционные выступления и поэтому навлекли на себя, как указывалось выше, гнев царских цензоров. Один из лучших, наиболее 
революционных рисунков Мельдермана так и не увидел света во время царского режима. Бережно хранимый Ю. Лилиенбахом более десяти лет, этот рисунок был опубликован впервые только после Великой Октябрьской социалистической революции во время советской власти в Эстонии, в феврале 1918 г. Напечатан он был в возобновленном издании Ю. Лилиенбаха «Таппер», 1918, № 3 - это был последний номер, вышедший в Таллине до оккупации Әстонии немецкими войсками. Ю. Лилиенбах снабдил рисунок следующим текстом: «Рисунок Х. Мельдермана, который не мог быть напечатан в царское время». Под рисунком помещено стихотворение «Воспоминание о 1905 годе», ясно указывающее на собы-

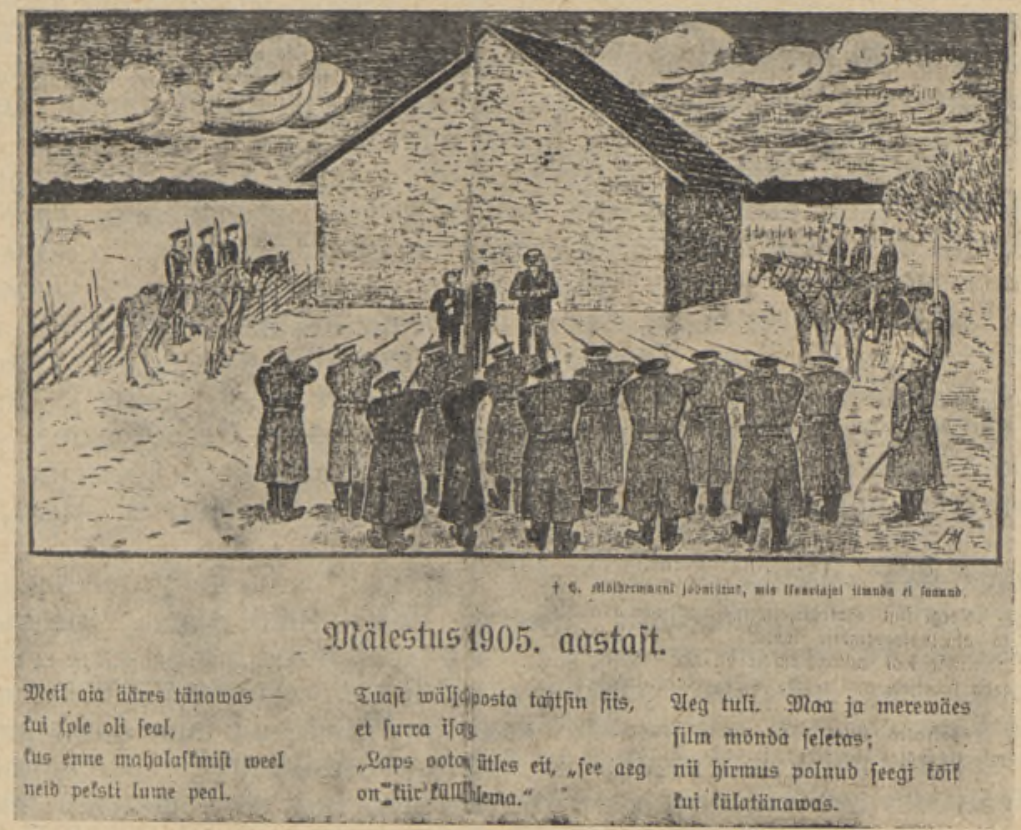

5. Исполнение судебного приговора. «Таппер», № 3, 1918, стр. 8/9.

тия, изображенные на рисунке. По всей вероятности, это «Исполнение судебного приговора», рисунок, указанный Лилиенбахом в первоначальном перечне рисунков на тему «Военное положение в Әстляндии».

В рисунке все подчинено главной идее произведения - показу героизма и мужества простых людей, эстонских крестьян, рядовых участников революции перед лицом смерти. Так же, как и многие русские художники, изображавшие казнь революционеров, Мельдерман раскрывает эту тему как убийство палачами лучших людей из народа.

В этом рисунке Мельдермана в непримиримом конфликте столкнулись две враждебные друг другу силы, столкнулись два мира: с одной стороны - представители революционного народа, с другой стороны царские сатрапы, стоящие на страже интересов самодержавия и эксплуататоров. И несмотря на то, что автор не ставил себе цели создать художественные образы борцов за народную свободу, что он только рассказывал о трагически закончившихся событиях, мы отчетливо чувствуем моральное превосходство крестьян-революционеров, победу тех, кто бесстрашно смотрят в лицо смерти. Ярче, осязательнее, чем в других рисунках, Мельдерман показал здесь свое отношение к изображенным событиям. Он разоблачает злодейское убийство, виновниками которого явля- 
ются самодержавие и бароны. Художник убежден, что народ непобедим, что его воля к свободе будет жить.

Сила эмоционального воздействия этого рисунка заключается в большой, суровой жизненной правде, переданной чутким художником, горячо любящим свой народ и ненавидящим его врагов, с взволнованностью и страстностью. «Исполнение судебного приговора» - это настоящий обвинительный акт против царского самодержавия. По своей жизненной правде этот рисунок перекликается с лучшими произведениями русской графики 1905-1907 годов.

Необходимо кратко остановиться на конкретно-исторической стороне изображенных на рисунке событий, помогающей глубже разобраться в них. Рисунок в точности воспроизводит картину расправы с крестьянами в Мярьяма в январе 1906 года и, следовательно, является ценным историческим документом. Нам известно, что «суд» над крестьянами Мярьяма состоялся 25 января. 11 человек были приговорены к расстрелу, из них только 3 человека очно. К телесному наказанию было приговорено 79 человек. Приговор был приведен в исполнение немедленно. Трое были расстреляны тут же у амбара на глазах населения волости, а порка продолжалась несколько часов. Многие из истязуемых были высланы в Сибирь ${ }^{15}$. Расстреляны были крестьяне Тынис Әрвин (из Велизе), Мадис Кюннапас и Яан Польдер. Старейшие жители Мярьяма помнят, что один из расстрелянных был очень сильный человек крупного роста ${ }^{16}$. Это был Тынис Әрвин, который перед смертью пытался убить Безобразова. Амбар, у которого расстреляли крестьян, уцелел до настоящего времени, хотя к нему сделана пристройка. Момент расстрела и изображен Мельдерманом.

Мельдерман упорно работал над художественно-документальной серией рисунков, отображающих события 1905-1906 годов. Чрезвычайно ценно именно то, что он пытается дать развернутое п о в е с т в о в а н и е об исторических событиях, раскрыть их в исторической последовательности и сущности. В листке «Ноолед» опубликован еще один рисунок, примыкающий непосредственно к художественно-документальной хронике Мельдермана. Несмотря на то, что под ним нет никакой подписи, можно предположить, что это «Могила революционера» (указан в перечне, данном Лилиенбахом). На рисунке изображено пустынное, заснеженное поле. Внизу, в левом углу рисунка, чернеет из-под снега нижний край тулупа и нога мужчины. Очевидно, это убитый карательным отрядом революционер.

Замыслы Мельдермана были обширнее, чем возможности для их осуществления. Цензурный гнет помешал ему расширить хронику. У него было намерение создать еще одну серию рисунков, которые охватили бы все основные узловые моменты революционной борьбы в Эстонии. M. Мельдре передала нам разграфленный на 10 частей лист, на котором три небольших рисунка-эскиза уже выполнены. На первом рисунке изображен митинг в Таллине, на Новом рынке, три следующие графы не заполнены, в пятой карандашом намечено помещичье имение, в шестой мы видим развалины разгромленного крестьянами помещичьего имения, на седьмом рисунке показано приближение конных стражников к крестьянскому хутору, о восьмом рисунке можно только предположить, что там художник собирался показать подожженную стражниками-карателями крестьянскую усадьбу. Три законченных эскиза выполнены тушью, как и вообще все его рисунки.

15 Г. И. М осбе рг, Указанная рукопись, стр. $651-652$.

16 Из устных воспомннаннй колхозницы Э. Поом из Мярьяма. 
Таким образом, мы видим, что здесь художник не повторяет того, что было им дано в первой хронике, а пытается дать новое, более обобщенное и развернутое повествование о революционных событиях в эстонской деревне.

В 1907 - 1914 годы Мельдерман продолжал систематически работать в области графики. В 1909 году в Таллине вышла книга «Eesti rahvanali» («Әстонский народный юмор»), иллюстрированная 120 рисунками Мельдермана. Во многих журналах того времени напечатаны его рисунки, карикатуры, иллюстрации и т. д. Художник оставил и целый ряд интересных портретов, среди которых особенно выделяется небольшого формата портрет Л. Толстого (карандаш). Сохранились также его пейзажи, из которых наиболее интересны «Вид на местечко Мярьяма» и «Озеро Юлемисте». Однако Мельдерман уже больше не мог подняться до уровня произведений, созданных в 1905-1907 годах.

Интенсивная и трудоемкая работа в цинкографии, систематическое чтение и рисование по ночам, переутомление - все это преждевременно подорвало здоровье Мельдермана. Заболев туберкулезом легких, он умер весной 1914 года в Мярьяма, на хуторе Кырветагузе.

Ханс Мельдерман имеет большие заслуги в развитии эстонского демократического искусства. В условиях, когда в Эстонии не было устойчивых традиций в области сатирической графики, Мельдерман самостоятельно добился выдающихся результатов.

Несмотря на то, что Мельдерману, не прошедшему школы рисунка и графической техники, не хватало подчас художественных навыков и мастерства для наиболее совершенного художественного воплощения свонх передовых идей и образов, его творчество было подлинным искусством, глубоко содержательным, правдиво отражавшим жизнь.

Мельдерман создал особый жанр журнального революционного рисунка в эстонском искусстве, специфика которого заключается в большой обличительной силе, правдивости, реализме, исторической документальности, в котором значительную роль играло и сатирическое начало.

Характерной чертой творчества Мельдермана является стремление к развернутой, повествовательной композиции. В этой области Мельдерман обладает большим талантом. Его композиции динамичны, они всегда построены на основе социального конфликта, на активном действии; действующие лица показаны в борьбе и движении. В этом смысле его рисунки по композиционным принципам близки к развернутым тематическим картинам.

Наиболее выдающимся произведением, знаменующим перелом не только в творчестве Мельдермана, но и в эстонском демократическом искусстве вообще, является художественно-документальная хроника Мельдермана «Военное положение в Эстляндии». Впервые в истории эстонского искусства Мельдерман сумел средствами изобразительного искусства показать остроту и непримиримость классовой борьбы.

Взяв за основу события, имевшие место в Эстонии, в местечке Мярьяма - одном из центров вооруженного выступления, - художник показал их типичность для народной революции, раскрыл их сущность как подлинную гражданскую войну между народом и господствующими классами. В этом его историческая и художественная заслуга.

Все произведения Мельдермана характеризуются большой силой обличения, правдивостью, реализмом. Их эмоциональное воздействие, агитирующее значение велико. Это убедительные и яркие р а с к а зы о ре- 
волюционных событиях в Эстонии, в то же время это исторические документы и гневные протесты, обвинения против жестокостей царизма и баронов.

Творчество Мельдермана успешно продолжало линию развития реалистического искусства в Эстонии. Оно является ярким доказательством существования сильного демократического направления в эстонском изобразительном искусстве, показывая в то же время, что реалистическое, народное искусство возникает только в самой тесной связи с жизнью и борьбой народа.

Творчество Мельдермана диаметрально противоположно и глубоко враждебно возникшему в годы революции реакционному, декадентскому, формалистическому направлению в эстонском искусстве. Декадентское искусство, объявившее себя носителем высшей красоты под лозунгом «искусство для искусства», в действительности характеризовалось реакщионными идеями, распадом художественной формы, бессилием создать художественные ценности.

Передовое идейное содержание, народность и революционный пафос поставили Мельдермана вместе с Лайкмаа впереди других эстонских художников того времени. Его творчество является ценным вкладом в сокровищницу эстонской демократической культуры.

Творчество Х. Мельдермана и других эстонских демократических художников, активно помогавших посредством своих рисунков и карика-тур общенародной борьбе против самодержавия в революции 19051907 годов, требует дальнейшего изучения.

Институт истории

Академии наук Эстонской ССР
Поступила в редакцию 29 IX 1954 